\title{
Grain Characteristics, Chemical Composition, and Functional Properties of Rye (Secale cereale L.) As Influenced by Genotype and Harvest Year
}

\author{
Hanne B. Hansen,,$\dagger$ Birthe Møller, ${ }^{\dagger}$ Sven B. Andersen, ${ }^{\S}$ \\ JOHANNES R. JøRGENSEN, ${ }^{\#}$ AND ÅSE HANSEN ${ }^{*}, \dagger$
}

\begin{abstract}
Department of Dairy and Food Science, The Royal Veterinary and Agricultural University (KVL), Rolighedsvej 30, DK-1958 Frederiksberg C, Denmark; Department of Agricultural Sciences, KVL, Thorvaldsensvej 40, DK-1871 Frederiksberg C, Denmark; and Department of Plant Biology, Danish Institute of Agricultural Sciences, Research Centre Flakkebjerg, DK-4200 Slagelse, Denmark
\end{abstract}

\begin{abstract}
Grain characteristic, chemical composition, and functional properties of rye were measured in 19 different cultivars grown in one location in up to 3 years. The cultivars included 8 adapted hybrids, 7 adapted population cultivars, and 4 nonadapted population cultivars. The results showed a significant influence of both harvest year and genotype on grain characteristics, chemical composition, and functional properties of the grain. Multivariate data analysis confirmed that the variations in the data were explained by yearly and genotype differences. Calculations of variance components showed that the variations in plant height, harvest yield, and protein content were mainly due to genotype differences and to a lesser extent to differences among harvest years. The kernel weight, hardness index, and content of dietary fiber components, however, were more strongly influenced by the harvest year than by the genotype. Differences in starch properties measured by falling number (FN), amylograph peak viscosity, and temperature at peak viscosity were more strongly influenced by harvest year. The water absorption was strongly influenced by genotype effects, compared to yearly differences. FN and amylograph peak temperature were positively correlated $(r=0.94)$. No correlation was found between the water absorption and the relative proportion of water-extractable arabinoxylan (AX) compared to the total AX content. However, the degree of ferulic acid cross-linking showed a negative correlation $(r=-0.70)$ with the water absorption.
\end{abstract}

KEYWORDS: Rye genotype; grain characteristic; rye flour; chemical components; dough properties

\section{INTRODUCTION}

A substantial part of the world rye harvest is used for bread baking, especially in central, northern, and eastern European countries where $>3$ million tonnes of rye is used for breadmaking per year (1). Thus, rye bread plays an important role in the nutrition of populations with high rye consumption, although the intake of rye has been declining for several years (1). The nutritional benefits of a high rye consumption include positive effects on digestion and decreased risk of heart disease, hypercholesterolemia, obesity, and non-insulin dependent diabetes, and probably rye also has a protective effect against some hormone-dependent cancer types (2-4). WHO (5) has declared that those diseases are among the diseases that create the greatest health problems in the European region.

* Corresponding author (telephone +45 352832 41; fax +45 352832 65; e-mail aah@kvl.dk).

Department of Dairy and Food Science, KVL

$¥$ Present address: The Danish Veterinary and Food Administration, Mørkhøj Bygade 19, DK-2860 Søborg, Denmark.

$\S$ Department of Agricultural Sciences, KVL.

\# Danish Institute of Agricultural Sciences.
Rye is a hardy crop, and the production of rye is environmentally friendly. Compared to wheat, rye can advantageously be grown in organic farming, due to reduced requirements of fertilizer and pesticides. Grain yields of rye, particularly those of the new hybrid cultivars, are comparable to wheat yields on good soils and superior on poor soils where wheat performs badly $(6,7)$. The term "population cultivar" designates rye cultivars bred by traditional breeding methods, compared to hybrid cultivars that are produced by the newer non-GMO hybrid breeding methods (8).

The test weight or weight of grain per unit volume is used as an index of rye grain quality, and minimum test weight specifications are an integral part of the rye grading systems of the European Community (EC) and other rye-producing countries (6). The minimum test weight requirement for intervention of rye in the European Union (EU) is $68.0 \mathrm{~kg} / \mathrm{hL}(9)$. The kernel weight of rye, measured as the weight of 1000 kernels, depends on grain density and size, and the kernel weight of rye grown in different countries ranged between 15.7 and $33.7 \mathrm{~g} / 1000$ kernels (6). 
The main chemical constituents of the rye grain are starch, dietary fiber (DF), protein, and mineral matter (ash). The starch content is limited mainly to the endosperm, and contents between 57.1 and $65.6 \mathrm{~g} / 100 \mathrm{~g}$ of dry matter $(\mathrm{dm})$ are reported in rye $(6,10)$. The DF components are found as cell-wall constituents in all parts of the kernel, and the total content of DF reported in rye grain is between 14.7 and $20.9 \mathrm{~g} / 100 \mathrm{~g}$ of $\mathrm{dm}(10-15)$. Approximately $25 \%$ of the total DF components are water-extractable (WE). Pettersson et al. (16) reported a range of variation in the proportion of WE to total DF of 25$30 \%$, whereas the variation found among the samples used in the present study was $20-32 \%$ (15). The main constituents of rye dietary fiber are arabinoxylans $(\mathrm{AX})$ or pentosans. The total content of AX reported in rye is between 6.5 and $12.2 \mathrm{~g} / 100 \mathrm{~g}$ of $\mathrm{dm}$ (17). The content of protein reported in rye cultivars, grown in different countries, was between 9.0 and $15.4 \mathrm{~g} / 100$ $\mathrm{g}$ of $\mathrm{dm}$, and the ash content was between 1.61 and $2.24 \mathrm{~g} / 100$ $\mathrm{g}$ of $\mathrm{dm}(6)$. The only low molecular weight sugar found in considerable amount in rye was sucrose $(0.7 \mathrm{~g} / 100 \mathrm{~g})$, whereas lower contents $(<0.1 \mathrm{~g} / 100 \mathrm{~g}$ of $\mathrm{dm})$ of glucose, fructose, raffinose, and stachyose were measured (18).

Rye grain contains enzymes that attack all of its major constituents, and especially the starch-degrading amylases play a key role in relation to the baking quality of the flour (6). The activity of the amylases is measured by the falling number (FN) method. Rye that is sound and not sprout-damaged normally has a $\mathrm{FN}$ in the range of $150 \mathrm{~s}$, and in dry years the FNs are $\sim 300 \mathrm{~s}$ and higher (6). The minimum FN requirement for intervention of rye in the EU was $100 \mathrm{~s}$ (9). A FN that is too low results in pasty and unacceptable bread. Problems with low $\mathrm{FN}$ in rye have been reduced considerably due to the breeding of new cultivars with better resistance to preharvest sprouting (19). A high content of pentosan has been suggested to have a protective effect against enzymatic breakdown of starch (20). The starch quality and the breakdown through activity of $\alpha$-amylase are also measured by the amylograph test. The maximum viscosity of a rye slurry heated in the amylograph and the temperature at maximum viscosity, which is normally reached between 62 and $75^{\circ} \mathrm{C}(21)$, are used as quality criteria.

The water absorption of rye flour is measured by the farinograph method. This quality parameter is correlated to the amount of water that can be added to the dough and thereby determines the economically important dough and bread yield achieved from a given amount of flour. The lack of gluten formation in a rye dough makes the role of the swelling substances (mainly AX) highly important for the dough structure (6). The water absorption is dependent on the content and properties of AX. Especially the proportion of water-extractable (WE) AX to total AX is considered to be important for water absorption $(22,23)$. The role of the rye proteins for the water absorption of rye whole meal and rye flour is probably low compared to wheat as a higher proportion of the rye proteins are water soluble (23). However, Dörfer (24) found that the addition of a protease to rye slurry caused a significant reduction of the viscosity.

In the milling and baking industry it is a well-known fact that rye quality can be highly different from one year to another. Relatively little attention, however, has been paid to the differences in rye grain quality due to rye genotypes. Contrary to the situation with wheat, the milling and baking industry normally do not have specific preferences regarding the rye cultivar. In addition, plant-breeding efforts with rye have not been as intensive as with wheat.
Only a few studies have dealt with the relative contribution of genotype and environment to the chemical composition and quality parameters of rye grain. Gan et al. (25) found a significant effect of genotype and environment on the extract viscosity of winter rye. Rattunde et al. (26) investigated the variation and covariation in milling and baking quality among 38 winter rye single crosses, grown in three environments in one year, and found a significant influence of the genotype. In another study with rye, Wilde and Weipert (27) found that environmental effects had by far the most important influence on the FN, amylograph peak viscosity, and peak temperature of rye compared to the effects of genotype and covariation. In a recent publication, significant effects of both harvest year and rye genotype on the content and composition of DF were demonstrated (28). With regard to the content of DF components, the yearly differences contributed more than genotype to the total variation. The degree of branching of the total and WE AX, however, was strongly influenced by the genotype (15). In a corresponding study of grain samples from the same study, significant differences in the content of phenolic acids were found among cultivars and harvest years (29). Some characteristic differences in dough yield and bread volume among cultivars of rye have also been reported (30), whereas replicated studies used to quantify the relative influence of genotype and harvest year on these parameters have not been published with rye.

The main purpose of the present study was to determine the relative contributions of genotype (cultivar) and harvest year to the total variation in grain characteristics, chemical composition, and functional properties related to the baking quality of rye. Another aim was to find correlations between grain characteristics, chemical composition, and functional properties of the grain by means of traditional correlation analysis as well as multivariate data analysis.

\section{MATERIALS AND METHODS}

Rye Samples. Nineteen different cultivars of rye were grown at the same location (The Danish Institute of Agricultural Sciences, located at Rønhave, Denmark; UTM 549238 eastern, 6090270 northern) in three growing seasons (1996/1997, 1997/1998, and 1998/1999). The cultivars included 8 hybrids (Rapid, Esprit, Amando, Ursus, Avanti, Apart, Marder, and Farino) and 11 population cultivars (Petkus II, Dominator, Motto, Quadriga, Nikita, Hacada, Amilo, Tsulpan3, Ponsi, Akusti, and Anna). The hybrids Marder and Farino were not grown in 1996/1997. The cultivars Tsulpan3, Ponsi, Akusti, and Anna were not adapted to the Danish climate, whereas the other 15 cultivars were adapted. The nonadapted cultivars are suited for growth in the northern parts of Scandinavia and Russia, where the climate is colder than in Denmark. Thus, the performance of these varieties might not be optimal in the Danish climate. The cultivars were included in the study in order to increase the genetic variability.

Each cultivar was grown in four replicated plots of $18 \mathrm{~m}^{2}$ size in a fully randomized block design. Grain samples from each plot were harvested, milled, and analyzed separately, and original seed material was used each year. Seeding rates were adjusted to give 300 plants $/ \mathrm{m}^{2}$ in $1996 / 1997$ and $1998 / 1999$ and 250 plants/m² in $1997 / 1998$. Fertilizer $(150 \mathrm{~kg}$ of $\mathrm{N} / \mathrm{ha}$ in $1996 / 1997$ and $130 \mathrm{~kg}$ of N/ha in the two following years) was given in three applications. Pesticides and growth regulators were used according to normal practice. The use of pesticides and growth regulators was constant from year to year. The soil at Rønhave is a sandy loam. The hybrids were grown as pure hybrids, where commercial hybrids today are mixed with $10 \%$ of population varieties in order to reduce the infection by ergot (31).

The climate conditions of the three years were in contrast with one another. The summer of 1997 and the harvest period in August were relatively warm and dry. The summer and the harvest time in 1998, however, were rainy, and the summer of 1999 was very warm. The 
degree of lodging was high in 1997 field plots, which is why the nitrogen supply was lowered from $150 \mathrm{~g} / \mathrm{ha}$ in $1996 / 1997$ to $130 \mathrm{~g} / \mathrm{ha}$ in the two following years. In 1998, the degree of lodging was also high, but this was explained by the wet climate of that year. In 1999, practically no lodging occurred except for the cultivar Tsulpan3.

Measurements of harvest yield, plant height, test weight, kernel weight, grain hardness index, protein content, FN, amylograph measurements, and water absorption were performed on 17 cultivars from all three harvest years and on the varieties Marder and Farino from the 1998 and 1999 harvests. Seven cultivars (Esprit, Amando, Ursus, Tsulpan3, Anna, Amilo, and Motto) grown during the three years were selected for performance of baking tests from which the results will be published in a separate paper. These selected cultivars were also used for measurements of content of low molecular sugars. Starch and ash contents were measured in 17 varieties from the 1997 harvest. All measurements were performed at least in duplicate on each grain sample (plot). Results are presented as mean values \pm standard deviation (SD) of at least two plots from the same cultivar and year.

Plant Height, Harvest Yield, and Grain Characteristics. Plant height $(\mathrm{cm})$ from the soil surface to the base of the spike was measured at maturity on plants from each plot. The harvest yield of each plot was measured and calculated as hkg of grain/hectare (ha) at $85 \%$ dry matter content. The 1000-kernel weight (g) was determined as the mean of three samples of 200 kernels and calculated as weight per 1000 kernels. Test weight was determined as the weight of $1 \mathrm{~L}$ of grain. Kernel hardness index was measured by the Single Kernel Characterization System 4100 (Perten Instruments, Huddinge, Sweden).

Milling of Grain Samples. Grain samples were milled on a hammer type cyclone mill (laboratory mill 120, Perten Instruments) with a 0.5 $\mathrm{mm}$ sieve (for measurements of protein, ash, starch, and low molecular weight sugars) and with an $0.8 \mathrm{~mm}$ sieve (for measurements of FN and amylograph viscosities). Rye grain for measurements of water absorption was milled to rye whole meal on a disk mill (type MHA 600 for 1997 and 1998 samples and type 400 for 1999 samples) (United Milling Systems, Copenhagen, Denmark). The particle size distribution of the whole meal was as follows: $>1 \mathrm{~mm}, 0.7-1.4 \%$; $500-1000$ $\mu \mathrm{m}, 20.6-24.5 \%$; 250-500 $\mu \mathrm{m}, 24.4-26.3 \%$; $160-250 \mu \mathrm{m}, 9.4-$ $10.1 \%$; and $<160 \mu \mathrm{m}, 38.6-43.8 \%$. The particle size distribution was similar to that of commercial Danish rye whole meal. The content of dry matter in the milled samples was measured according to ICC standard 110/1 (32). All values were calculated on a dry matter basis.

Chemical Analysis. Protein, Ash, and Starch. The content of raw protein was determined in the grain samples by Kjeldahl determination (ICC method 105/1) (32). Ash content was determined according to ICC method 104/1 (32). The content of starch was measured according to the enzymatic colorimetric method as described by Bach Knudsen et al. (33).

Low Molecular Weight Sugars. The content of glucose, fructose, saccharose, and maltose was determined by HPLC. The milled grain sample $(1.0 \mathrm{~g}$, particle size $<0.5 \mathrm{~mm})$ was mixed with internal standard $(1.0 \mathrm{~mL}$ of erythritol solution, $20 \mathrm{mg} / \mathrm{mL})$ and extracted with warm ethanol $\left(9.0 \mathrm{~mL}, 96 \%, 80^{\circ} \mathrm{C}\right)$. The suspension was mixed by using an Ultra-Turrax T-25 (Janke and Kunkel GmbH) and centrifuged (3000 rpm, 30 min, room temperature) in a Sorvall RC-5 centrifuge (Dupont Instruments). The extract was filtered through a $0.45 \mu \mathrm{m}$ Minisart filter. Sugars were separated by HPLC (Varian Chromatography Systems, Walnut Creek, CA) with a Supelcosil LC-NH 2 column $(25 \mathrm{~cm}+4.6$ $\mathrm{cm} ; 5 \mu \mathrm{m}$, no. 58338$)$ and acetonitrile/water (82:18) as eluent $(1.2 \mathrm{~mL} /$ min). Sugars were quantified by refractive index detection (Varian Star 9040, Varian Chromatography Systems). All extracts were prepared in duplicate on each grain sample.

Dietary Fiber Components. The content and composition of dietary fiber, including total, WE, and water-unextractable (WUE) DF, mixedlinkage $\beta$-glucan, and fructan was determined in samples from all 19 cultivars from which the seven selected cultivars were analyzed all three years. The methods of the dietary fiber measurements as well as detailed data on DF in the samples are described by Boskov Hansen et al. (15). Only selected data from the DF analyses are presented in this paper. For more details on the DF content and composition, please refer to the previous publication (15).
Functional Properties. Falling Number and Amylograph Measurements. The FN was determined according to ICC standard 107 (32). Amylograph measurements were performed with a Viscograph E (Brabender OHG, Duisburg, Germany) according to ICC standard method 126/1 (32). The maximum viscosity in Brabender units (BU), temperature at maximum viscosity $\left({ }^{\circ} \mathrm{C}\right)$, and temperature at the beginning of gelatinization $\left({ }^{\circ} \mathrm{C}\right)$ were registered.

Water Absorption. The water absorption of rye whole meal was measured as described in the standard methods (ICC method 115/1) $(32,34)$ with some modifications: $200 \mathrm{~g}$ of flour (14\% moisture basis) was mixed in a $300 \mathrm{~g}$ farinograph bowl (at $30 \mathrm{rpm}$ ) with demineralized water to a final dough consistency of $300 \pm 10 \mathrm{BU}$ after $10 \mathrm{~min}$ of kneading time. The water absorption was calculated as $(x+y-200) /$ 2 , where $x=$ water added $(\mathrm{mL})$ and $y=$ actual amount of flour added according to the correction table for $14 \%$ moisture content (AACC method 82-24) (35).

Statistical Analysis. All statistical analyses were performed by means of SAS software, version 8.2, SAS Institute Inc., Cary, NC. The significant effects of genotype (cultivar), harvest year, and their interactions on the quality parameters were determined by a two-way analysis of variance and covariance (GLM procedure) on data from the 17 cultivars grown in all three years. A general model for the statistical analysis was

$$
X_{i j k}=\mu+\gamma_{k}+Y_{i}+G_{j}+(Y \times G)_{i j}+\epsilon_{i j k}
$$

where $X_{i j k}$ was the observation within the $i$ th year $\left(Y_{i}\right)$ of the $j$ th genotype $\left(G_{j}\right)$ in the $k$ th replicate $\left(\gamma_{k}\right), \mu$ was the overall mean, $(Y \times G)_{i j}$ was the interaction, and $\epsilon_{i j k}$ was an error term. Variance components were calculated by means of the procedure VARCOMP (SAS) using the restricted maximum-likelihood method (REML). Significance levels in the paper refer to the test results in a fixed effects model, whereas, for the calculation of variance components, genotype and year were treated as random factors.

Effects of genotype within each harvest year were tested by a oneway analysis of variance. Significant differences among mean values were found by a multiple $t$ test (Tukeys $t$ test; $P<0.05$ ). Pearson correlation coefficients $(r)$ were calculated between all of the measured parameters [including the DF data reported earlier (15) across cultivars and years]. All measurements presented in the paper were performed on replicate experimental units (plots), and data are presented as mean value \pm standard deviation (SD)

Multivariate Data Analysis. A principal component analysis (PCA) was performed on all samples and all variables according to the method of Martens and Næs (36) using the software Unscrambler (37). The content of total DF, which was reported by Boskov Hansen et al. (15), was included in the PCA. The aim of the PCA algorithm was to determine the latent factors or principal components (PCs) in the data set, which described most variation. On the basis of vector algebra the data material was compressed into scores for principal components, which were plotted on a score plot. Scores placed near each other indicate that the samples act similarly. The included variables were expressed as loadings and plotted together with the scores in a biplot. A score placed near a loading indicates a high influence by the variable.

\section{RESULTS}

Plant Height, Harvest Yield, and Grain Characteristics. The measured parameters plant height, harvest yield, and grain characteristics showed a large range of variation among cultivars (Table 1) and less variation among harvest years (Table 4). A significant influence of harvest year, genotype, and covariation was found (Table 4). Characteristic differences in plant height and harvest yield were found among adapted hybrids, adapted population cultivars, and nonadapted population cultivars (Table 1).

Plant Height. The plant height ranged between 135 and 194 $\mathrm{cm}$. Hybrid cultivars were generally slightly lower than adapted population cultivars and much lower than nonadapted cultivars 
Table 1. Characteristics of Rye Grain from Different Cultivars Grown under the Same Conditions in 1996/1997, 1997/1998, and 1998/1999

\begin{tabular}{|c|c|c|c|c|c|c|c|c|c|c|c|c|c|c|c|c|}
\hline \multirow[b]{2}{*}{ cultivar } & \multirow[b]{2}{*}{ group $^{a}$} & \multicolumn{3}{|c|}{$\begin{array}{c}\text { harvest yield } \\
\text { (hkg/ha) }\end{array}$} & \multicolumn{3}{|c|}{$\begin{array}{l}\text { plant ht } \\
\text { (cm) }\end{array}$} & \multicolumn{3}{|c|}{$\begin{array}{c}\text { kernel wt } \\
\text { (g/1000 kernels) }\end{array}$} & \multicolumn{3}{|c|}{$\begin{array}{c}\text { test } w t \\
\text { (g/L of grain) }\end{array}$} & \multicolumn{3}{|c|}{ hardness index } \\
\hline & & 1997 & 1998 & 1999 & 1997 & 1998 & 1999 & 1997 & 1998 & 1999 & 1997 & 1998 & 1999 & 1997 & 1998 & 1999 \\
\hline Rapid & $\mathrm{H}$ & 95.2 & 84.7 & 90.3 & 152 & 150 & 144 & 31.6 & 28.8 & 39.9 & 766 & 752 & 794 & 45.8 & 46.6 & 55.3 \\
\hline Esprit & $\mathrm{H}$ & 93.4 & 89.3 & 101.2 & 154 & 151 & 143 & 29.9 & 27.5 & 36.9 & 769 & 740 & 793 & 41.1 & 41.7 & 47.0 \\
\hline Amando & $\mathrm{H}$ & 84.9 & 80.3 & 90.8 & 155 & 153 & 135 & 27.3 & 25.9 & 32.6 & 767 & 744 & 785 & 51.1 & 56.6 & 54.7 \\
\hline Ursus & $\mathrm{H}$ & 89.2 & 89.5 & 104.1 & 145 & 148 & 140 & 29.4 & 26.0 & 36.1 & 755 & 730 & 794 & 43.5 & 46.7 & 51.5 \\
\hline Avanti & $\mathrm{H}$ & 99.7 & 94.6 & 104.1 & 149 & 148 & 138 & 31.0 & 27.3 & 34.6 & 760 & 739 & 786 & 48.6 & 51.2 & 57.3 \\
\hline Apart & $\mathrm{H}$ & 84.4 & 81.1 & 93.8 & 151 & 155 & 146 & 32.1 & 28.6 & 37.0 & 774 & 750 & 794 & 46.0 & 48.0 & 56.2 \\
\hline Marder & $\mathrm{H}$ & $-^{e}$ & 81.7 & 96.1 & - & 146 & 140 & - & 24.5 & 31.9 & - & 734 & 790 & - & 48.4 & 52.3 \\
\hline Farino & $\mathrm{H}$ & - & 89.5 & 103.4 & - & 143 & 135 & - & 25.9 & 34.3 & - & 738 & 796 & - & 40.6 & 48.9 \\
\hline Petkus II & $P$ & 72.3 & 68.2 & 68.0 & 158 & 160 & 149 & 31.1 & 28.0 & 36.8 & 764 & 743 & 796 & 43.3 & 45.8 & 50.8 \\
\hline Dominator & $P$ & 78.3 & 76.5 & 87.2 & 157 & 158 & 148 & 28.8 & 27.3 & 35.5 & 766 & 751 & 802 & 43.0 & 46.1 & 55.3 \\
\hline Motto & $P$ & 79.8 & 71.7 & 78.5 & 161 & 165 & 146 & 33.1 & 30.0 & 37.1 & 781 & 754 & 792 & 46.9 & 46.1 & 52.2 \\
\hline Quadriga & $P$ & 78.8 & 73.7 & 89.3 & 145 & 148 & 140 & 28.6 & 25.4 & 33.0 & 776 & 752 & 806 & 46.6 & 46.2 & 55.2 \\
\hline Nikita & $P$ & 77.3 & 74.5 & 83.5 & 151 & 156 & 149 & 32.8 & 29.1 & 37.0 & 761 & 747 & 798 & 44.9 & 45.2 & 52.2 \\
\hline Hacada & $P$ & 68.3 & 69.8 & 85.7 & 159 & 164 & 151 & 29.3 & 28.4 & 36.5 & 772 & 753 & 804 & 44.3 & 43.6 & 53.6 \\
\hline Amilo & $P$ & 80.8 & 72.5 & 79.6 & 155 & 159 & 159 & 31.8 & 29.1 & 37.0 & 779 & 753 & 794 & 48.8 & 48.0 & 54.6 \\
\hline Tsulpan3 & $\mathrm{P}_{1}$ & 61.7 & 53.7 & 51.4 & 155 & 168 & 144 & 30.5 & 25.1 & 34.3 & 748 & 719 & 726 & 47.4 & 52.5 & 49.1 \\
\hline Ponsi & $P_{1}$ & 61.5 & 51.3 & 58.3 & 168 & 179 & 158 & 25.7 & 20.4 & 28.9 & 743 & 702 & 756 & 46.2 & 50.0 & 51.8 \\
\hline Akusti & $P_{1}$ & 52.4 & 56.2 & 67.4 & 168 & 178 & 151 & 27.0 & 22.3 & 27.6 & 771 & 737 & 782 & 43.5 & 47.8 & 49.5 \\
\hline Anna & $P_{1}$ & 56.9 & 52.8 & 59.9 & 180 & 194 & 173 & 28.7 & 23.9 & 28.6 & 747 & 715 & 756 & 45.1 & 47.1 & 47.6 \\
\hline signifb & & 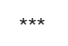 & $\star \star \star *$ & *** & *** & $* \star \star$ & $\star \star \star *$ & $\star \star \star *$ & $\star \star \star *$ & *** & $\star \star \star *$ & 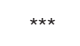 & *** & $\star \star * *$ & 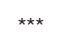 & *** \\
\hline LSD value ${ }^{c}$ & & 15.0 & 7.3 & 8.9 & 5 & 7 & 23 & 5.1 & 2.3 & 2.9 & 31 & 18 & 9 & 5.7 & 5.3 & 3.8 \\
\hline & & 4 & 4 & 4 & 4 & 4 & 4 & 4 & 4 & 4 & 4 & 4 & 4 & 3 & 4 & 4 \\
\hline \multicolumn{17}{|l|}{ group means } \\
\hline $\mathrm{H}$ & & 91.1 & 86.3 & 98.0 & 151 & 149 & 140 & 30.2 & 26.8 & 35.4 & 765 & 741 & 791 & 46.0 & 47.5 & 52.9 \\
\hline$P$ & & 76.5 & 72.4 & 81.7 & 155 & 158 & 149 & 30.8 & 28.2 & 36.1 & 771 & 750 & 799 & 45.4 & 45.9 & 53.4 \\
\hline$P_{1}$ & & 58.1 & 53.5 & 59.3 & 168 & 179 & 156 & 28.0 & 22.9 & 29.8 & 752 & 718 & 755 & 45.6 & 49.3 & 49.5 \\
\hline
\end{tabular}

${ }^{a} \mathrm{H}$, hybrid; $\mathrm{P}$, population cultivar; $\mathrm{P}_{1}$, nonadapted population cultivars. ${ }^{b}$ Significance level for the effect of genotype within each harvest year: ${ }^{* \star *}, P<0.1 \%$; ${ }^{* *}, P=$ $0.1-1.0 \%$; ${ }^{*}, P=1.0-5.0 \%$; ns, nonsignificant $(P>5 \%) .{ }^{C}$ Least significant difference between means in the same column. ${ }^{d} n=$ number of grain samples (plots) analyzed from each cultivar. ${ }^{e}$ The cultivar was not grown in 1997.

(Table 1). Genotype effects were high (52\% of total variance), compared to yearly effects $(23 \%)$ and covariance $(7 \%)$ (Table 4).

Harvest Yield. Harvest yields ranged from 51 to $104 \mathrm{hkg} / \mathrm{ha}$ among all varieties and harvest years (Table 1). The harvest yield was influenced the most by the rye genotype, which accounted for $80 \%$ of the variation, whereas yearly differences contributed only $8 \%$ of the total variance (Table 4). Adapted hybrid cultivars produced $10-20 \%$ higher yields compared to adapted population cultivars, whereas nonadapted population cultivars produced much lower harvest yields than adapted cultivars (Table 1). The highest yields were achieved in the warm summer of 1999, with a mean harvest yield among the 17 cultivars of $82 \mathrm{hkg} / \mathrm{ha}$ compared to $77 \mathrm{hkg} / \mathrm{ha}$ in 1997 and $73 \mathrm{hkg} / \mathrm{ha}$ in 1998 (Table 4).

Test Weight and Kernel Weight. The test weight ranged from 702 to $806 \mathrm{~g} / \mathrm{L}$, and weight per 1000 kernels ranged from 20.4 g (Ponsi, 1998) to 39.9 g (Rapid, 1999) (Table 1). Test and kernel weights were highly influenced by both harvest year (63 and 65\%) and genotype (23 and 25\%) (Table 4). The test weight and kernel weight were highest in 1999 (786 g/L, $35 \mathrm{~g} / 1000$ kernels) and lowest in 1998 (740 g/L and $27 \mathrm{~g} / 1000$ kernels) (Table 4). Generally, the adapted cultivars had higher test weight and kernel weight than the nonadapted cultivars (Table 1).

Grain Hardness Index. Grain hardness index ranged from 41 to 57 (Table 1). As a mean of the three harvest years Esprit had the softest kernels, whereas Avanti was the cultivar with the hardest kernels (Table 1). The variation in grain hardness index was most influenced by the harvest year $(51 \%)$, with a lower influence of the genotype (19\%) (Table 4). The mean value of grain hardness index was highest in $1999(53 \pm 3)$ and lowest in $1997(46 \pm 1)$.
Chemical Composition. Protein Content. The protein content ranged from 8.0 to $11.3 \mathrm{~g} / 100 \mathrm{~g}$ of $\mathrm{dm}$ (Table 2). The cultivar Anna had the highest protein content $(10.0-11.3 \mathrm{~g} / 100 \mathrm{~g}$ of $\mathrm{dm})$, whereas the lowest content was measured in the hybrid cultivar Farino (7.9 g/100 $\mathrm{g}$ of $\mathrm{dm}$ ). The protein content was significantly influenced by both genotype and harvest year; however, the influence of the genotype was very high $(67 \%)$ (Table 4). The nonadapted cultivars generally had the highest protein content and the adapted hybrid cultivars the lowest protein content (Table 2).

Starch and Ash Content. The starch content of the 17 cultivars harvested in 1997 ranged between 57.0 and $62.5 \mathrm{~g} / 100 \mathrm{~g}$ of dm (Table 2), and significant differences were found among the genotypes. In general, grain from the nonadapted cultivars with high protein content contained less starch $(58.0 \mathrm{~g} / 100 \mathrm{~g}$ of $\mathrm{dm})$ compared to adapted hybrids $(60.7 \mathrm{~g} / 100 \mathrm{~g}$ of $\mathrm{dm})$ and adapted population cultivars $(61.5 \mathrm{~g} / 100 \mathrm{~g}$ of $\mathrm{dm})$.

The ash content ranged from 1.8 to $2.2 \mathrm{~g} / 100 \mathrm{~g}$ of dm among the 17 cultivars harvested in 1997 (Table 2), and significant differences were found among the genotypes. The nonadapted cultivars showed a slightly higher ash content than adapted hybrids and adapted population cultivars.

Low Molecular Weight Sugars. Sucrose was the low molecular weight sugar found in highest amount in the rye samples, but the concentration was rather low $(0.4-0.7 \mathrm{~g} / 100 \mathrm{~g}$ of $\mathrm{dm})$ (data not shown). No significant difference in sucrose content was found among harvest years or groups of cultivars. Only traces $(<0.1 \mathrm{~g} / 100 \mathrm{~g}$ of $\mathrm{dm})$ of fructose, glucose, and maltose could be detected in the samples (data not shown).

Dietary Fiber. The content of AX ranged from 8.7 to 11.5 $\mathrm{g} / 100 \mathrm{~g}$ of $\mathrm{dm}$, and the proportion of WE AX relative to total AX varied between 26 and 39\% among cultivars and harvest 
Table 2. Content of Protein, Total Arabinoxylan (AX), Water-Extractable (WE) AX, Proportion of WE to Total AX, Ash, and Starch in Different Rye Cultivars Grown under the Same Conditions in 1996/1997, 1997/1998, and 1998/1999

\begin{tabular}{|c|c|c|c|c|c|c|c|c|c|c|c|c|c|c|c|}
\hline \multirow[b]{2}{*}{ cultivar } & \multirow[b]{2}{*}{ group $^{a}$} & \multicolumn{3}{|c|}{$\begin{array}{c}\text { protein } \\
(\mathrm{g} / 100 \mathrm{~g} \text { of } \mathrm{dm})\end{array}$} & \multicolumn{3}{|c|}{$\begin{array}{c}\text { total AX } \\
(\mathrm{g} / 100 \mathrm{~g} \text { of } \mathrm{dm})\end{array}$} & \multicolumn{3}{|c|}{$\begin{array}{c}\text { WE AX } \\
(\mathrm{g} / 100 \mathrm{~g} \text { of } \mathrm{dm})\end{array}$} & \multicolumn{3}{|c|}{$\begin{array}{c}\text { WE/total } A X^{e} \\
(\%)\end{array}$} & \multirow{2}{*}{$\frac{\begin{array}{c}\text { ash } \\
(\mathrm{g} / 100 \mathrm{~g} \text { of } \mathrm{dm})\end{array}}{1997}$} & \multirow{2}{*}{$\begin{array}{c}\begin{array}{c}\text { starch } \\
(\mathrm{g} / 100 \mathrm{~g} \text { of } \mathrm{dm})\end{array} \\
1997\end{array}$} \\
\hline & & 1997 & 1998 & 1999 & 1997 & 1998 & 1999 & 1997 & 1998 & 1999 & 1997 & 1998 & 1999 & & \\
\hline Rapid & $\mathrm{H}$ & 8.9 & 8.6 & 8.4 & 8.0 & 10.0 & - & 2.7 & 3.3 & - & 34 & 34 & - & 1.9 & 61.6 \\
\hline Esprit & $\mathrm{H}$ & 9.1 & 8.2 & 8.1 & 8.8 & 9.9 & 10.0 & 2.7 & 3.2 & 3.0 & 31 & 33 & 30 & 1.8 & 60.7 \\
\hline Amando & $\mathrm{H}$ & 9.7 & 9.0 & 8.9 & 9.6 & 9.7 & 10.5 & 3.6 & 3.8 & 3.3 & 37 & 39 & 31 & 1.9 & 60.1 \\
\hline Ursus & $\mathrm{H}$ & 8.6 & 8.1 & 8.6 & 8.7 & 10.7 & 10.0 & 3.0 & 3.4 & 2.6 & 34 & 32 & 26 & 1.9 & 59.9 \\
\hline Avanti & $\mathrm{H}$ & 8.6 & 8.1 & 8.0 & 8.6 & 9.6 & - & 3.0 & 3.5 & - & 33 & 36 & - & 1.8 & 61.0 \\
\hline Apart & $\mathrm{H}$ & 9.1 & 8.8 & 8.3 & 8.9 & 10.2 & - & 3.4 & 3.7 & _- & 38 & 36 & - & 1.9 & 60.8 \\
\hline Marder & $\mathrm{H}$ & - & 8.9 & 8.7 & - & 10.3 & 9.6 & - & 3.4 & 3.3 & - & 33 & 34 & - & - \\
\hline Farino & $\mathrm{H}$ & - & 7.9 & 7.9 & - & 10.4 & 10.0 & - & 4.0 & 3.1 & - & 38 & 31 & - & - \\
\hline Petkus II & $P$ & 9.6 & 9.2 & 9.0 & 9.0 & 8.9 & - & 3.0 & 2.7 & - & 33 & 30 & - & 1.8 & 60.6 \\
\hline Dominator & $P$ & 9.4 & 8.5 & 8.1 & 9.0 & 10.0 & - & 3.2 & 3.5 & - & 35 & 35 & - & 1.9 & 62.5 \\
\hline Motto & $P$ & 9.2 & 8.9 & 8.9 & 8.3 & 9.0 & 8.9 & 3.1 & 3.0 & 2.9 & 37 & 34 & 33 & 1.8 & 61.0 \\
\hline Quadriga & $\mathrm{P}$ & 8.7 & 8.4 & 8.1 & 8.8 & 9.4 & - & 3.5 & 3.0 & - & 40 & 32 & - & 1.9 & 61.8 \\
\hline Nikita & $\mathrm{P}$ & 9.5 & 8.8 & 8.7 & 9.1 & 9.8 & - & 3.3 & 3.5 & - & 36 & 36 & - & 1.8 & 60.7 \\
\hline Hacada & P & 9.3 & 8.9 & 8.4 & 8.8 & 8.7 & - & 3.5 & 3.1 & - & 40 & 36 & - & 1.8 & 62.2 \\
\hline Amilo & $P$ & 9.4 & 9.3 & 9.2 & 9.0 & 10.5 & 10.9 & 3.0 & 2.9 & 4.0 & 33 & 27 & 36 & 1.9 & 61.5 \\
\hline Tsulpan3 & $P_{1}$ & 10.4 & 9.9 & 10.6 & 9.0 & 10.5 & 9.6 & 3.4 & 3.0 & 2.7 & 38 & 29 & 27 & 2.2 & 57.8 \\
\hline Ponsi & $P_{1}$ & 10.5 & 9.8 & 9.9 & 9.0 & 12.1 & - & 2.9 & 3.7 & - & 32 & 31 & - & 1.9 & 59.1 \\
\hline Akusti & $P_{1}$ & 11.2 & 10.2 & 9.4 & 8.5 & 10.8 & - & 2.9 & 3.2 & - & 34 & 29 & - & 2.0 & 57.0 \\
\hline Anna & $P_{1}$ & 11.3 & 10.3 & 10.0 & 9.3 & 11.5 & 10.9 & 3.5 & 3.5 & 3.8 & 38 & 31 & 34 & 2.0 & 58.3 \\
\hline signif $b$ & & $* * *$ & $* * *$ & $* * *$ & * & * & ns & ** & ns & ns & ** & ns & ns & ** & $* * *$ \\
\hline LSD value $^{c}$ & & 0.8 & 1.2 & 1.2 & 1.2 & 3.1 & 3.8 & 0.9 & - & - & 9 & - & - & 0.4 & 3.8 \\
\hline$n^{d}$ & & 3 & 2 & 2 & 3 & 2 & 2 & 3 & 2 & 2 & 3 & 2 & 2 & 3 & 3 \\
\hline \multicolumn{16}{|l|}{ group means } \\
\hline $\mathrm{H}$ & & 9.0 & 8.5 & 8.4 & 88 & 101 & 100 & 3.1 & 3.5 & 3.0 & 35 & 35 & 30 & 1.9 & 60.7 \\
\hline P & & 9.3 & 8.8 & 8.6 & 88 & 95 & 99 & 3.2 & 3.1 & 3.5 & 36 & 33 & 35 & 1.9 & 61.5 \\
\hline$P_{1}$ & & 10.8 & 10.0 & 10.0 & 90 & 112 & 102 & 3.2 & 3.4 & 3.2 & 36 & 30 & 31 & 2.0 & 58.0 \\
\hline
\end{tabular}

${ }^{a} \mathrm{H}$, hybrid; $\mathrm{P}$, population cultivar; $\mathrm{P}_{1}$, nonadapted population cultivars. ${ }^{b}$ Significance level for the effect of genotype within each harvest year: ${ }^{* \star *}, P<0.1 \% ;{ }^{* \star}, P=$ $0.1-1.0 \% ;{ }^{*}, P=1.0-5.0 \%$; ns, nonsignificant $(P>5 \%)$. ${ }^{c}$ Least significant difference between means in the same column. ${ }^{d} n=$ number of grain samples analyzed from each cultivar; - , not measured. ${ }^{e}$ Proportion of WE AX to total AX content (\%).

years (Table 2). A significant influence of genotype (20\%) and harvest year $(38 \%)$ was found on the total content of $\mathrm{AX}$, whereas no significant differences were found in the content of WE AX or the proportion of WE AX to total AX (Table 4). The content of other dietary fiber components (e.g., total DF and mixed linkage $\beta$-glucan) has been reported earlier (15). Please refer to that paper for more detailed information on the DF content and composition of the rye samples.

Functional Properties. Falling Number. The FN of the grain samples ranged from $82 \mathrm{~s}$ (Tsulpan3) to $358 \mathrm{~s}$ (Amilo) (Table 3). The FN was most influenced by harvest year, which accounted for $77 \%$ of the total variance, whereas the effect of genotype accounted for only $11 \%$ (Table 4). The mean FN was only $129 \mathrm{~s}$ in the rainy summer of 1998 compared to $242 \mathrm{~s}$ in 1997 and $287 \mathrm{~s}$ in 1999. The cultivars Amilo and Ponsi were least influenced by the weather conditions, whereas the FNs of the cultivars Anna, Apart, Tsulpan3, and Rapid were dramatically lowered in the rainy summer of 1998 due to higher activities of $\alpha$-amylases (Table 3). No differences were found among the three groups of cultivars (Table 3).

Amylograph Gelatinization Properties. The amylograph peak viscosity ranged from 387 to $1114 \mathrm{BU}$, the temperature at peak viscosity varied between 61.0 and $76.7^{\circ} \mathrm{C}$, and the temperature at the beginning of gelatinization ranged between 49.2 and 52.7 ${ }^{\circ} \mathrm{C}$ (Table 3). Yearly differences accounted for $49-70 \%$ of the total variance of the amylograph parameters, whereas the estimated influence of genotype was only 13-23\% (Table 4). The mean maximal viscosity was as low as $498 \mathrm{BU}$ in the rainy summer of 1998 compared to $637 \mathrm{BU}$ in 1997 and $843 \mathrm{BU}$ in 1999. The cultivars Amilo and Ponsi had very high gelatinization temperatures $\left(>73{ }^{\circ} \mathrm{C}\right)$ in the warm summers in 1997 and 1999 combined with high amylograph viscosities. The cultivar Farino had very high viscosity in 1999 , but not a very high peak temperature. Corresponding to the effects on the FN, the gelatinization temperatures for Amilo and Ponsi were least influenced by the rainy weather conditions in 1998, whereas the cultivars Anna, Apart, Tsulpan3, and Rapid showed low peak viscosities and temperatures at peak viscosity below 62 ${ }^{\circ} \mathrm{C}$ (Table 3). No general differences were seen in amylograph parameters between the different groups of cultivars (Table 3).

Water Absorption. The water absorption of rye whole meal ranged from 63.8 to $70.6 \%$ (Table 3). The cultivars Amando and Tsulpan3 generally had high water absorption values, whereas other cultivars, such as Nikita, had low water absorption capacities. The water absorption was mostly influenced by genotype effects (42\%) and less by yearly variations (16\%) (Table 4). The average water absorption was lowest in 1997 (65.9\%) compared to 1998 (66.9\%) and 1999 (67.1\%).

Correlations. Grain Characteristics and Chemical Composition. In general, the high-yielding adapted rye cultivars had bigger kernels, with a higher content of starch and lower contents of protein, ash, and dietary fiber compared to low-yielding nonadapted cultivars, which had higher contents of protein. As could be expected, the harvest yield was positively correlated with kernel weight $(r=0.46)$, test weight $(r=0.53)$, and content of starch $(r=0.45)$. The content of protein in the grain was negatively correlated with harvest yield $(r=-0.78)$, kernel weight $(r=-0.32)$, and test weight $(r=-0.37)$, and similar correlations were found between the ash content and harvest yield $(r=-0.50)$ and test weight $(r=-0.31)$, whereas no correlation between ash content and kernel weight was found (data not shown). 
Table 3. Falling Number and Amylograph Data of Rye Grain from Different Cultivars Grown under the Same Conditions in 1996/1997, 1997/1998, and 1998/1999

\begin{tabular}{|c|c|c|c|c|c|c|c|c|c|c|c|c|c|c|c|c|}
\hline \multirow[b]{2}{*}{ cultivar } & \multirow[b]{2}{*}{ group $^{a}$} & \multicolumn{3}{|c|}{$\begin{array}{l}\text { falling no. } \\
\text { (s) }\end{array}$} & \multicolumn{3}{|c|}{$\begin{array}{l}\text { amylograph viscosity } \\
\text { (BU) }\end{array}$} & \multicolumn{3}{|c|}{$\begin{array}{c}\text { gelatinization temp } \\
\left({ }^{\circ} \mathrm{C}\right)\end{array}$} & \multicolumn{3}{|c|}{$\begin{array}{l}\text { temp at beginning } \\
\text { of gelatinization }\left({ }^{\circ} \mathrm{C}\right)\end{array}$} & \multicolumn{3}{|c|}{$\begin{array}{c}\text { water absorption } \\
(\mathrm{mL} / 100 \mathrm{~g} \text { of wholemeal) }\end{array}$} \\
\hline & & 1997 & 1998 & 1999 & 1997 & 1998 & 1999 & 1997 & 1998 & 1999 & 1997 & 1998 & 1999 & 1997 & 1998 & 1999 \\
\hline Rapid & $\mathrm{H}$ & 193 & 94 & 240 & 517 & 445 & 637 & 65.6 & 61.0 & 68.3 & 49.7 & 50.0 & 51.7 & 67.1 & 68.5 & 66.9 \\
\hline Esprit & $\mathrm{H}$ & 218 & 131 & 304 & 593 & 533 & 900 & 66.3 & 63.0 & 72.1 & 50.4 & 51.0 & 52.4 & 65.2 & 66.7 & 65.6 \\
\hline Amando & $\mathrm{H}$ & 145 & 117 & 307 & 472 & 552 & 854 & 63.1 & 62.2 & 72.5 & 50.1 & 49.3 & 50.9 & 68.4 & 70.6 & 70.4 \\
\hline Ursus & $\mathrm{H}$ & 241 & 110 & 317 & 795 & 488 & 1114 & 67.2 & 63.6 & 72.1 & 50.2 & 51.1 & 51.7 & 65.0 & 64.8 & 66.5 \\
\hline Avanti & $\mathrm{H}$ & 251 & 175 & 329 & 752 & 612 & 985 & 68.3 & 66.8 & 72.0 & 50.5 & 50.3 & 51.3 & 66.1 & 64.6 & 66.9 \\
\hline Apart & $\mathrm{H}$ & 244 & 94 & 237 & 615 & 387 & 740 & 67.2 & 61.6 & 68.3 & 49.5 & 50.4 & 51.5 & 66.5 & 67.2 & 69.6 \\
\hline Marder & $\mathrm{H}$ & - & 160 & 266 & - & 535 & 752 & - & 63.1 & 69.7 & - & 51.6 & 52.8 & - & 67.9 & 67.6 \\
\hline Farino & $\mathrm{H}$ & - & 133 & 323 & - & 657 & 1379 & - & 63.8 & 72.2 & - & 50.7 & 52.2 & - & 66.5 & 65.9 \\
\hline Petkus II & $P$ & 224 & 131 & 299 & 548 & 439 & 826 & 67.0 & 63.8 & 73.1 & 51.1 & 50.8 & 51.7 & 65.0 & 64.9 & 67.6 \\
\hline Dominator & P & 219 & 117 & 256 & 538 & 433 & 685 & 67.3 & 63.4 & 68.3 & 51.7 & 51.1 & 52.2 & 64.4 & 66.0 & 68.1 \\
\hline Motto & $\mathrm{P}$ & 249 & 110 & 277 & 716 & 508 & 863 & 70.1 & 63.1 & 70.6 & 50.6 & 50.7 & 52.5 & 63.8 & 66.8 & 66.6 \\
\hline Quadriga & $\mathrm{P}$ & 242 & 120 & 259 & 609 & 536 & 769 & 69.0 & 63.0 & 69.4 & 51.5 & 50.9 & 52.0 & 65.2 & 66.6 & 66.7 \\
\hline Nikita & $\mathrm{P}$ & 209 & 124 & 297 & 504 & 421 & 784 & 67.3 & 63.2 & 72.3 & 52.2 & 50.1 & 51.5 & 65.1 & 65.1 & 65.1 \\
\hline Hacada & $P$ & 251 & 116 & 304 & 734 & 533 & 951 & 69.1 & 64.5 & 71.7 & 50.6 & 50.1 & 51.5 & 65.7 & 65.8 & 65.9 \\
\hline Amilo & $P$ & 358 & 230 & 311 & 826 & 629 & 819 & 73.6 & 68.4 & 74.2 & 49.2 & 50.1 & 52.3 & 66.4 & 67.2 & 67.8 \\
\hline Tsulpan3 & $P_{1}$ & 211 & 82 & 257 & 609 & 437 & 812 & 66.2 & 61.2 & 69.3 & 50.7 & 50.9 & 52.7 & 67.7 & 69.3 & 70.6 \\
\hline Ponsi & $P_{1}$ & 332 & 233 & 318 & 798 & 619 & 949 & 76.7 & 71.7 & 75.6 & 51.1 & 51.5 & 52.4 & 65.6 & 67.5 & 65.8 \\
\hline Akusti & $P_{1}$ & 258 & 123 & 296 & 594 & 443 & 899 & 69.9 & 65.0 & 72.7 & 51.0 & 50.8 & 52.6 & 65.9 & 68.5 & 65.2 \\
\hline Anna & $P_{1}$ & 272 & 95 & 265 & 607 & 455 & 742 & 69.3 & 61.8 & 70.7 & 50.2 & 50.0 & 52.0 & 67.2 & 67.3 & 65.9 \\
\hline signif $^{b}$ & & $* * *$ & $\star * *$ & $\star * *$ & $\star * *$ & * & $\star \star *$ & $\star * *$ & $\star * *$ & $\star \star *$ & ** & $\star * *$ & $* * *$ & ** & ns & ** \\
\hline LSD value ${ }^{c}$ & & 96 & 44 & 31 & 203 & 292 & 199 & 4.6 & 4.3 & 2.5 & 2.5 & 0.8 & 0.9 & 3.4 & 6.4 & 4.5 \\
\hline$n^{d}$ & & 3 & 4 & 4 & 3 & $2^{e}$ & $2^{e}$ & 3 & $2^{e}$ & $2^{e}$ & 3 & $2^{e}$ & $2^{e}$ & 2 & $2^{e}$ & $2^{e}$ \\
\hline \multicolumn{17}{|l|}{ group means } \\
\hline $\mathrm{H}$ & & 215 & 127 & 290 & 624 & 526 & 920 & 66.3 & 63.1 & 70.9 & 50.1 & 50.5 & 51.8 & 66.4 & 67.1 & 67.4 \\
\hline$P$ & & 250 & 135 & 286 & 639 & 500 & 813 & 69.0 & 64.2 & 71.4 & 51.0 & 50.8 & 52.0 & 65.1 & 66.1 & 66.8 \\
\hline$P_{1}$ & & 268 & 133 & 284 & 652 & 488 & 850 & 70.5 & 64.9 & 72.1 & 50.8 & 50.8 & 52.4 & 66.6 & 68.1 & 66.9 \\
\hline
\end{tabular}

${ }^{a} \mathrm{H}$, hybrid; $\mathrm{P}$, population cultivar; $\mathrm{P}_{1}$, nonadapted population cultivars. ${ }^{b}$ Significance level for the effect of genotype within each harvest year: ${ }^{* * *}, P<0.1 \% ;{ }^{* *}, P=$ $0.1-1.0 \%$; ${ }^{*}, P=1.0-5.0 \%$; ns, nonsignificant $(P>5 \%)$. ${ }^{C}$ Least significant difference between means in the same column. ${ }^{d} n=$ number of grain samples (plots) analyzed from each cultivar; - , not measured. ${ }^{e}$ Nonbaking cultivars: measurements on one plot from each cultivar.

Table 4. Grain Characteristics, Chemical Composition, and Baking Quality Parameters of Rye Whole Meal from 17 Different Cultivars Grown in the Same Location in Denmark in 1996/1997, 1997/1998, and 1998/1999

\begin{tabular}{|c|c|c|c|c|c|c|c|}
\hline & \multirow{2}{*}{$\begin{array}{c}\text { range of } \\
\text { variation }^{a}\end{array}$} & \multicolumn{3}{|c|}{$\begin{array}{c}\text { grain quality and chemical composition, } \\
\text { means of harvest years }\end{array}$} & \multicolumn{3}{|c|}{$\begin{array}{l}\text { analysis of variance and } \\
\text { variance components }{ }^{c}(\%)\end{array}$} \\
\hline & & 1997 & 1998 & 1999 & year $(Y)$ & genotype $(G)$ & $\operatorname{covar} Y \times G$ \\
\hline \multicolumn{8}{|l|}{ grain characteristics } \\
\hline yield (hkg/ha) & $51-104$ & $77 \pm 14$ & $73 \pm 13$ & $82 \pm 16$ & $* * *(8)$ & $* * *(80)$ & $* * *(5)$ \\
\hline plant ht $(\mathrm{cm})$ & $135-194$ & $157 \pm 9$ & $161 \pm 13$ & $148 \pm 9$ & $* \star \star(23)$ & $* \star \star(52)$ & $* \star *(7)$ \\
\hline test wt ( $g / L)$ & $702-806$ & $765 \pm 11$ & $740 \pm 15$ & $786 \pm 21$ & ${ }^{* \star *}(63)$ & $* \star \star *(23)$ & $* * \star(7)$ \\
\hline kernel wt (g) & $20-40$ & $30 \pm 2$ & $27 \pm 3$ & $35 \pm 3$ & ${ }^{* * *}(65)$ & $* \star *(25)$ & $* * \star(5)$ \\
\hline hardness index & $41-57$ & $46 \pm 1$ & $48 \pm 3$ & $53 \pm 3$ & $* * *(51)$ & $* * *(19)$ & $* * *(17)$ \\
\hline $\begin{array}{l}\text { protein } \\
\text {. }\end{array}$ & $8.0-11.3$ & $9.6 \pm 0.8$ & $9.0 \pm 0.7$ & $8.9 \pm 0.7$ & $* \star *(17)$ & $* * *(67)$ & * (4) \\
\hline total dietary fiber ${ }^{d}$ & $15.4-20.9$ & $16.1 \pm 0.7$ & $17.9 \pm 1.2$ & $18.9 \pm 1.5$ & $* * *(49)$ & $* *(14)$ & ns \\
\hline total arabinoxylan $(\mathrm{AX})^{d}$ & $8.7-11.5$ & $9.1 \pm 0.4$ & $10.2 \pm 0.8$ & $10.1 \pm 0.7$ & ${ }^{* \star *}(38)$ & ${ }^{* *}(20)$ & ns \\
\hline WE $A X^{d}$ & $2.6-4.0$ & $3.2 \pm 0.3$ & $3.3 \pm 0.3$ & $3.2 \pm 0.6$ & ns & ns & ns \\
\hline WE/total AX $(\%)^{d}$ & $26-39$ & $35 \pm 3$ & $32 \pm 4$ & $31 \pm 4$ & ns & ns & ns \\
\hline \multicolumn{8}{|l|}{ baking quality parameters } \\
\hline $\mathrm{FN}(\mathrm{s})$ & $82-358$ & $242 \pm 49$ & $129 \pm 44$ & $287 \pm 29$ & ${ }^{\star \star \star}(77)$ & $* * *(11)$ & $\star * \star *(8)$ \\
\hline amylograph max viscosity (BU) & $387-1114$ & $637 \pm 112$ & $498 \pm 75$ & $843 \pm 118$ & ${ }^{* * *}(70)$ & $* * *(15)$ & ** $(7)$ \\
\hline gel temp $\left({ }^{\circ} \mathrm{C}\right)$ & $61.0-76.7$ & $68.4 \pm 3.1$ & $64.0 \pm 2.8$ & $71.4 \pm 2.1$ & ${ }^{* * *}(63)$ & $* * \star(23)$ & $* *(6)$ \\
\hline gel start $\left({ }^{\circ} \mathrm{C}\right)$ & $49.2-52.7$ & $50.6 \pm 0.8$ & $50.5 \pm 0.6$ & $51.9 \pm 0.5$ & $* \star \star(49)$ & ${ }^{*}(13)$ & ns \\
\hline water abs (\%) & $63.8-70.6$ & $65.9 \pm 1.2$ & $66.9 \pm 1.7$ & $67.1 \pm 1.7$ & $* * \star(16)$ & $* * \star(42)$ & ns \\
\hline
\end{tabular}

${ }^{a}$ Range of variation among cultivars and harvest years. ${ }^{b}$ Mean $\pm \mathrm{SD} ; n=17 .{ }^{c}$ Influence of genotype $(\mathrm{G})$, harvest year $(\mathrm{Y})$, and covariation $(\mathrm{G} \times \mathrm{Y})$ : ${ }^{* \star \star}, P<0.1 \%$; **, $P=0.1-1.0 \%$; ${ }^{*}, P=1.0-5.0 \%$; ns, nonsignificant $(P>5.0 \%)$; variance components in parentheses. Relative contribution to the total variance $(=100 \%)$. Difference to $100 \%=$ replication and error variance contribution. ${ }^{d} n=7$ (data from seven cultivars: Esprit, Amando, Ursus, Tsulpan3, Anna, Amilo, and Motto).

Functional Properties. The FN was positively correlated to kernel weight $(r=0.59)$ and the content of $\beta$-glucan in the grain $(r=0.64)$, whereas no correlation was found between the FN and the contents of protein, ash, starch, total dietary fiber, total $\mathrm{AX}$, or the proportion of WE $\mathrm{AX}$ to total $\mathrm{AX}$ (data not shown). As expected, the FN showed a strong positive correlation with amylograph peak viscosity $(r=0.78)$ and temperature at peak viscosity ( $r=0.94$; data not shown). The content of $\beta$-glucan was also positively correlated with the amylograph peak viscosity $(r=0.52)$ and temperature at peak viscosity $(r=0.50)$. The starch content measured in samples from harvest 1997 was not correlated to amylograph data (data 


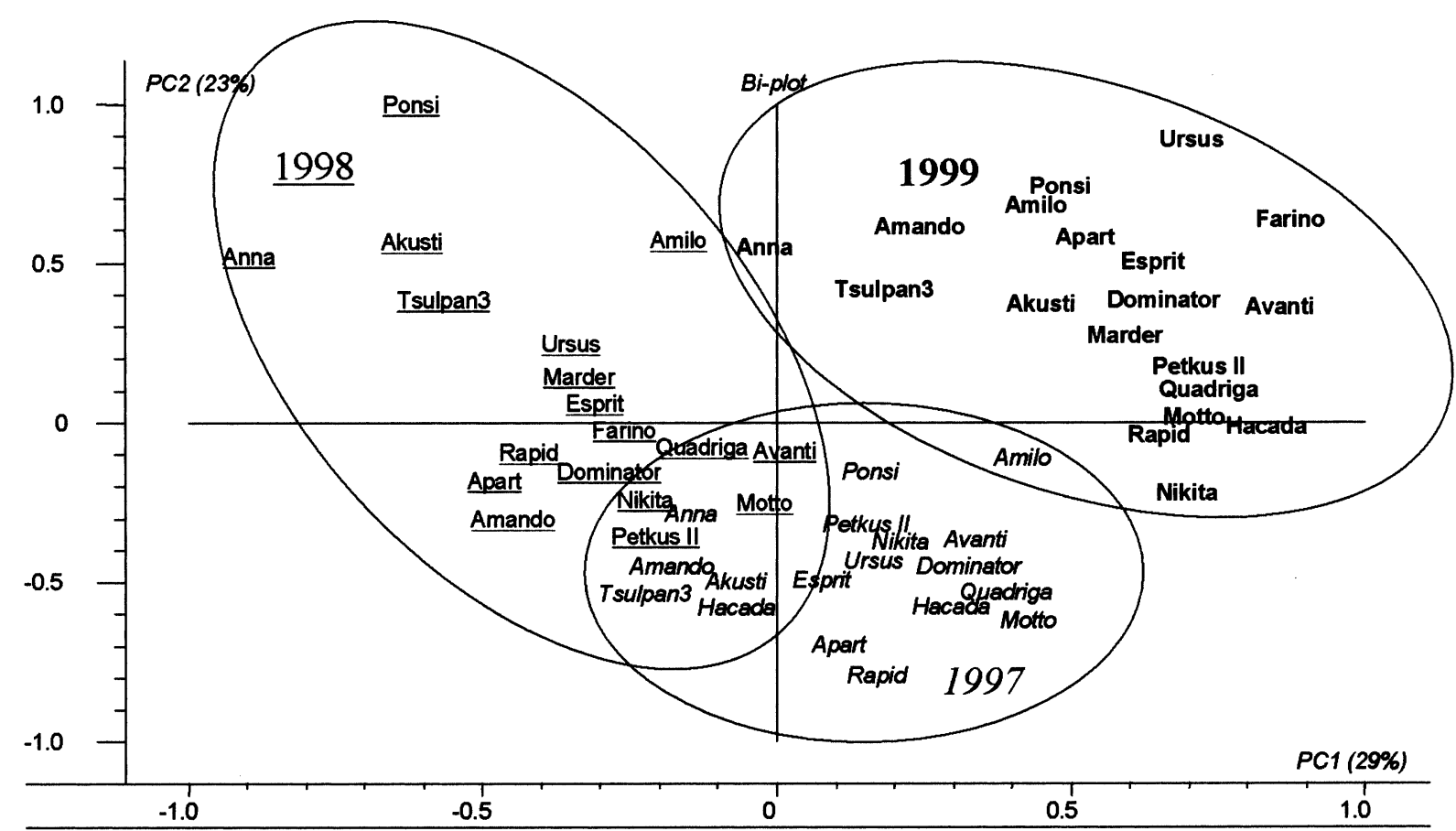

Figure 1. Biplot (PC1:PC2) for all samples and variables (loadings not shown, see Figure 2). Samples harvested in 1997 are in italic; 1998 , underlined; and 1999, in bold.

not shown). The contents of protein, ash, and dietary fiber components had no influence on the amylograph properties.

The water absorption of rye whole meal was positively correlated with grain hardness index ( $r=0.57$; data not shown). No correlation was found between harvest yield, kernel weight, or test weight of the grain and the water absorption of rye whole meal. The water absorption showed also no correlation with the content of protein, ash, starch, or ferulic acid in the grain [contents of ferulic acid and other phenolic acids in the samples have been reported by Andreasen et al. (38)]. Only a weak positive overall correlation was found between the water absorption and the content of total DF $(r=0.31)$ and total AX $(r=0.33)$. Contrary to statements made by Drews (22) and Weipert (23), no correlation was found between the water absorption and the proportion of WE AX to total AX. The ara/ xyl ratio of the total $\mathrm{AX}$ was also not correlated with water absorption, whereas the ara/xyl ratio of WUE AX showed a significant negative correlation with water absorption $(r=$ -0.32). A positive correlation between the total AX content and the water absorption within the same cultivar was found for some of the cultivars, whereas other cultivars showed no increase in water absorption with increasing AX content. The cultivars that showed a positive correlation between the total AX content and water absorption were Amando $(r=0.52$; $n=7)$, Amilo ( $r=0.64 ; n=7)$, Akusti $(r=0.83 ; n=3)$, Farino $(r=0.77 ; n=4)$, Nikita $(r=0.54 ; n=3)$, Motto $(r=0.59 ; n=6)$, Rapid $(r=0.94 ; n=3)$, Tsulpan3 $(r=0.41 ; n=7)$, Quadriga $(r=0.98 ; n=4)$, and Ponsi $(r=0.78 ; n=4)$. The $\beta$-glucan content of the grain was not correlated with the water absorption. The amount of fructan, which was relatively high in the rye samples (15), was not correlated with any of the measured baking quality parameters (data not shown).

The content of ferulic acid and ferulic acid dimers was measured in the 17 cultivars from 1997 and in four cultivars from 1998 (Ponsi, Tsulpan, Esprit, and Motto), which were selected for their different contents in 1997 harvest (29). The molar ratio of arabinose to ferulic acid was 48:1 in 1997 and
59:1 in 1998 samples. A much higher degree of ferulic acid cross-linking was found in 1997 samples, with a mean molar ratio of arabinose to ferulic acid dehydrodimers of 297:1 compared to the molar ratio of 423:1 in 1998 samples (15). This lower degree of cross-linking found in the 1998 samples might explain the higher water absorption of rye wholemeal from 1998 grain samples compared to grain from 1997 (Table 3). A negative correlation $(r=-0.34 ; n=20)$ was found between the degree of cross-linking of the AX, measured as the amount of diferulic acid in relation to the content of arabinose in the DF, and the water absorption (data not shown). The cultivar Motto had a lower water absorption than the other cultivars but the same degree of cross-linking. When the data for Motto (two samples) were eliminated, the correlation coefficient $(r)$ between the degree of cross-linking and the water absorption of the measured cultivars in 1997 and 1998 was $-0.70(n=18)$. No correlation was found between the degree of cross-linking and the relative proportion of WE to total AX in the samples (Table 2).

Multivariate Data Analysis. The results of the PCA from all data confirm and visualize the results of the variance analysis. Figure 1 shows the relative position of the cultivars from each of the three harvest years in a plot of the first and second PCs, which describes most variation (52\% of the total variance). The samples divide roughly into three groups according to the different harvest years. The effect of genotype is also clearly seen as the different cultivars are roughly placed in the same position relative to each other within each harvest year. The samples harvested in the rainy summer of 1998 are placed in the left part of the plot, whereas the samples harvested in the very warm summer in 1999 are nearer to the top right corner. Intermediate are the samples harvested in the warm and dry summer in 1997. Figure 2 shows the same cultivars according to groups, $\mathrm{H}$ (adapted hybrids), $\mathrm{P}$ (adapted population cultivars), and $\mathrm{P}_{1}$ (nonadapted population cultivars) together with the loadings of the included variables. Within the circles illustrating the harvest year in Figure 2 the nonadapted cultivars $\left(\mathrm{P}_{1}\right)$ are placed nearer the top left part of the plot, whereas the adapted 


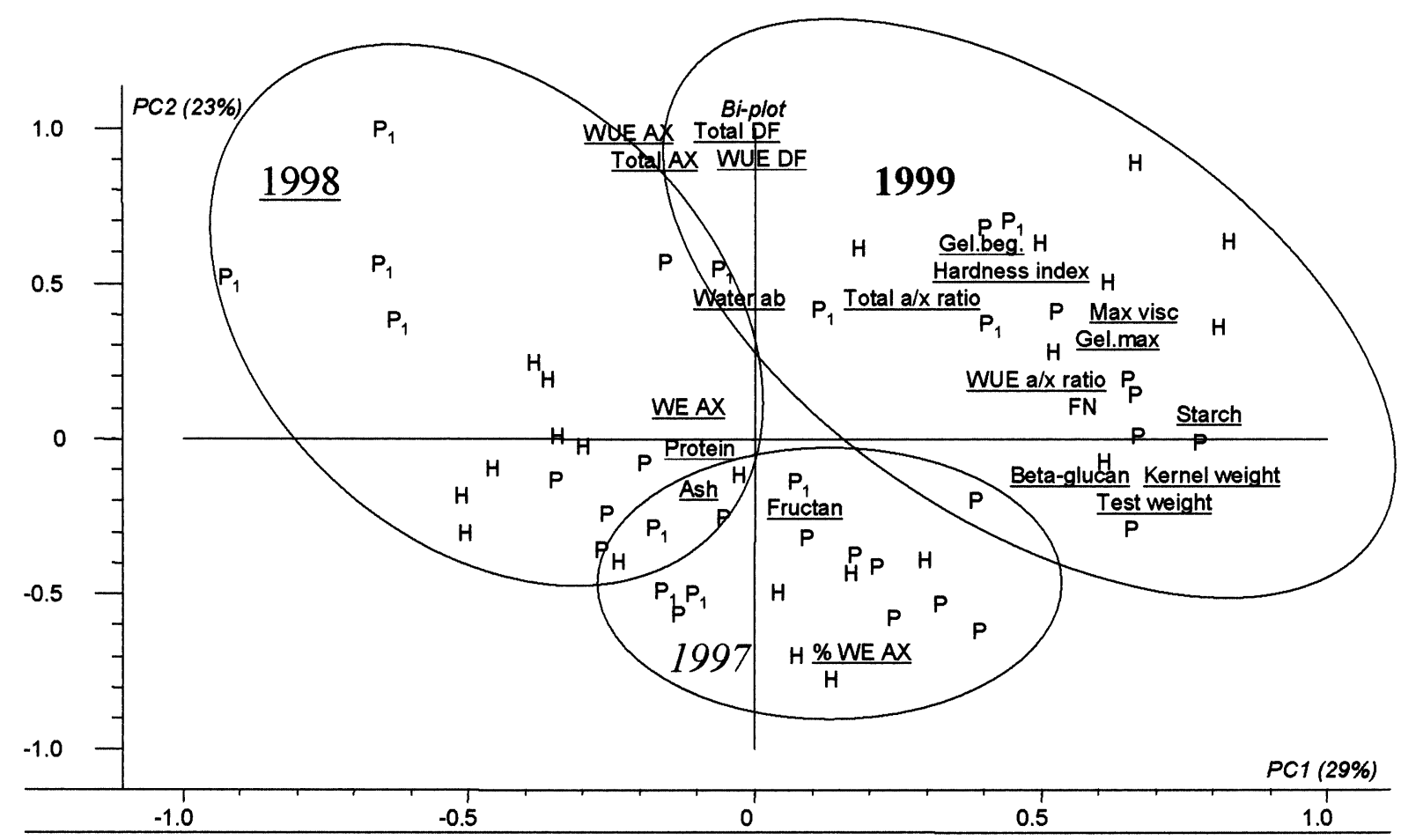

Figure 2. Biplot (PC1:PC2) for all samples and variables divided after groups. Loadings are underlined (for further explanation see Table 1). $\mathrm{H}$, hybrid; $P$, adapted; $P_{1}$, nonadapted.

cultivars $(\mathrm{P}$ and $\mathrm{H})$ are placed in the bottom and right parts of the plot. The division according to year of harvest and groups was even clearer when a PCA was performed if the variables yield and plant height were included (plot not shown).

\section{DISCUSSION}

Plant Height, Harvest Yield, and Grain Characteristics. The high range of variation in harvest yield, plant height, kernel weight, and grain hardness index found in this study illustrates the high diversity of the rye plant and kernels due to genetic and yearly differences (Tables 1 and 4). The harvest yield and plant height were mostly influenced by the rye genotype (52$80 \%$ of the total variance). Kernel weight, test weight, and grain hardness index, however, were influenced more by yearly variation compared to variation among cultivars. In a study of the impact of weather on yield components of winter rye over 30 years, Chmielewski and Kohn (39) observed that the kernel weight was negatively influenced by high temperature and drought during the ripening stage as this weather situation reduced the duration of the grain-filling period. Warm and sunny weather in the autumn and an early start of the growing season after winter increased the crop density, kernel number, and yield (39). As expected, the harvest yield of hybrid cultivars was 10$20 \%$ higher than that of population cultivars, which has also been reported by Geiger (8). Plant heights were greatly different even though growth regulator was used on all cultivars each year. The kernel weight and test weight were relatively high compared to data reported by Seibel and Weipert (6). The grain hardness index of rye has not been reported earlier, but the present results show that grain hardness can vary considerably between rye cultivars and harvest years.

Chemical Composition. The most important variance component for the protein content measured in the present study was the genotype, compared with much lower effects of harvest year and interaction. The lower protein content of modern hybrid cultivars found in this study is in accordance with findings by Wilde and Weipert (27). The role of the rye proteins in relation to breadbaking is considered to be low, as no gluten network is formed in a rye dough $(29,40)$. The relevance of the observed differences in protein content in relation to the baking performance of the grain is not known. No correlation was found between the total protein content and the water absorption of the grain. The ash content probably has no technological importance. The low content of low molecular weight sugars found in the present study has also been reported by other authors $(12,18)$. The content of starch measured in this study is in accordance with findings by other authors (6).

Functional Properties. The variation in the starch properties FN, amylograph viscosity, and gelatinization temperature found in this study (Table 3) is in accordance with the range of variation reported by other authors $(6,41)$. The high influence of the harvest year compared to genotype effects confirms the high susceptibility of the rye starch quality to weather conditions. Although significant differences were found among the cultivars, only minor differences were found among the three groups of cultivars, which indicates that the high-yielding hybrid cultivars have starch properties similar to those of population cultivars. A high influence of the environment on starch properties (FN, amylograph peak viscosity, peak temperature) was also reported by Wilde and Weipert (27), who found that estimates of genotype and covariation effects were only $7.4-27.5 \%$ of the total variance among rye grain from different cultivars and locations in Germany. Selection of young material in the breeding programs is mainly based on FN, which may also affect the amylograph properties. No correlation was found between the FN and the total AX content, but a positive correlation existed between the $\mathrm{FN}$ and the content of $\beta$-glucan in the samples. As reported earlier, the content of $\beta$-glucan was positively correlated with kernel weight (15). Thus, it seems that cultivars with high $\beta$-glucan content and big kernels tend to have a higher protection against low FN. 
The water absorption of the rye samples showed a large range of variation among cultivars and harvest years. The water absorption was mostly influenced by the genotype compared to a much lower yearly variation. As the water absorption is related to the content and properties of the $\operatorname{DF}(22,23)$, especially AX, one could speculate that differences in content or structure of DF components are responsible for the differences in water absorption. A significant influence of the genotype was found on the content of DF and AX (15). With inclusion of all samples, only a weak positive correlation was found between the total amount of DF or AX and the water absorption of the flour. Some cultivars, however, showed a positive correlation between the total content of AX and the water absorption. This indicates that not only the amount but also the "quality" of the $\mathrm{AX}$ is important in regard to the water absorption. The relative proportion of WE AX to total AX showed a high range of variation $(26-39 \%)$, which is in accordance with the findings of Bengtson et al. (42) (19.8-37.5) and Weipert (41) (20.7$31.5 \%$ ), but no correlation was found between this proportion and the water absorption of the flour. The observed high influence of the genotype on the viscous properties of the grain was most likely caused by differences in AX structure, such as the degree of branching and/or ferulic acid cross-linking of AX molecules, as well as the molecular size of the AX. The negative correlation found between the water absorption and the ara/xyl ratio of the WUE AX together with the high genotype influence on the ara/xyl ratio of the WUE AX (15) confirms that these parameters are important. The results show that a high degree of branching of the WUE AX and a high degree of ferulic acid cross-linking of the AX are related to a low water absorption of the rye whole meal. The molecular size of AX was not measured in this study but might also be important. Arabinoxylan molecules of various molecular sizes have been reported within the WE AX (43) and solubilized WUE AX fractions of rye grain (44). Furthermore, Gan et al. (25) found that the rye extract viscosity was dependent on the genetic variation of rye, and Scoles et al. (45) found that it was correlated with the proportion of high molecular weight $(>500 \mathrm{kDa}) \mathrm{AX}$ in the WE AX. The fact that the water absorption of rye is much more dependent on the rye genotype than on yearly variation means that bakeries could benefit from selecting a specific rye cultivar with a relatively high water absorption for their production.

\section{ABBREVIATIONS USED}

dm, dry matter; AX, arabinoxylan; DF, dietary fiber; SD, standard deviation.

\section{ACKNOWLEDGMENT}

We thank Food Technician Jakob Zeuthen, Department of Dairy and Food Science, KVL, for skillful performance of the quality parameter measurements.

\section{LITERATURE CITED}

(1) FAOSTAT statistical database; FAO Food and Agriculture Organization: Rome, Italy, 1998.

(2) Kritchevsky, D. Dietary fibre in health and disease. In Advanced Dietary Fibre Technology; McCleary, B., Prosky, L., Eds.; Blackwell Science: London, U.K., 2001.

(3) Adlercreutz, H. Western Diet and Western Diseases-Some Hormonal and Biochemical-Mechanisms and Associations. Scand. J. Clin. Lab. Invest. 1990, 50, 3-23.

(4) Zhang, J. X.; Lundin, E.; Reuterving, C. O.; Hallmans, G.; Stenling, R.; Westerlund, E.; Åman, P. Effect of rye bran, oat bran and soy bean fibre on lipid and bile metabolisms, and gallbladder morphology in male syrian hamsters. In Proceedings of Fibre 90, Dietary Fibre: Chemical and biological aspects; special publication 83; Southgate, D. A. T., Waldron, K., Johnson, I. T., Fenwick, G. R., Eds.; The Royal Society of Chemistry: Norwich, U.K., 1990.

(5) WHO. WHO Health 21-Health for all in the 21st century; WHO: Geneve, Switzerland, 1998.

(6) Seibel, W.; Weipert, D. Bread baking and other food uses around the world. In Rye: Production Chemistry and Technology; Bushuk, W., Ed.; American Association of Cereal Chemists: St. Paul, MN, 2001.

(7) Karpenstein-Machan, M.; Maschka, R. Investigations on yield structure and local adaptability of triticale, hybrid-rye and population-rye based on data of regional cultivar trails. Agribiol. Res. 1996, 49, 130-143.

(8) Geiger, H. H. Züchtung. In Roggen-Anbau, Verarbeitung, Markt; Seibel, W., Stenling, R., Eds.; Behrs: Hamburg, Germany, 1988.

(9) European Communities Commission Regulation (EC) 1424/98 of 3 July 1998 amending Regulation (EEC) 689/92 fixing the procedures and conditions for the taking-over of cereals by intervention agencies. Off. J. Eur. Communities 1998, 41, 1415.

(10) Nilsson, M.; Åman, P.; Harkonen, H.; Hallmans, G.; Knudsen, K. E. E.; Mazur, W.; Adlercreutz, H. Nutrient and lignan content, dough properties and baking performance of rye samples used in Scandinavia. Acta Agric. Scand. 1997, 47, 26-34.

(11) Plaami, S.; Saini, H.,S.; Kumpulainen, J. Effects of variety and environment on dietary fibre content of winter rye in Finland. J. Cereal Sci. 1989, 10, 209-215.

(12) Knudsen, K. E. B. Carbohydrate and lignin contents of plant materials used in animal feeding. Anim. Feed Sci. Technol. 1997, 67, 319-338

(13) Harkonen, H.; Pessa, E.; Suortti, T.; Poutanen, K. Distribution and some properties of cell wall polysaccharides in rye milling fractions. J. Cereal Sci. 1997, 26, 95-104.

(14) Glitso, L. V.; Knudsen, K. E. B. Milling of whole grain rye to obtain fractions with different dietary fibre characteristics. $J$. Cereal Sci. 1999, 29, 89-97.

(15) Hansen, H. B.; Rasmussen, C.,V.; Knudsen, K.,E. B.; Hansen, $\AA$. Effect of genotype and harvest year on content and composition of dietary fibre in rye (Secale cereale L.) grain. J. Sci. Food Agric. 2003, 83, 76-85.

(16) Pettersson, D.; Åman, P. Enzyme supplementation of a poultry diet containing rye and wheat. Br. J. Nutr. 1989, 62, 139-149.

(17) Vinkx, C. J. A.; Delcour, J. A. Rye (Secale cereale L) arabinoxylans: A critical review. J. Cereal Sci. 1996, 24, 1-14.

(18) Henry, R. J.; Saini, H. S. Characterization of Cereal Sugars and Oligosaccharides. Cereal Chem. 1989, 66, 362-365.

(19) Weipert, D. Pentosans as selection traits in rye breeding. Vortr. Pflanzenzuechtung 1996, 35, 109-119.

(20) Weipert, D. Sprouting damage and processing value of ryeeffect of $\alpha$-amylase activity and pentosan content. In Pre-harvest Sprouting in Cereals 1992; Walker-Simonds, M. K., Ried, J. L., Eds.; American Association of Cereal Chemists: St. Paul, MN, 1993.

(21) Drews, E.; Seibel, W. Bread baking around the world. In Rye, Production, Chemistry and Technology; Bushuk, W., Ed.; American Association of Cereal Chemists: St. Paul, MN, 1976.

(22) Drews, E. Die Bedeutung der Schleimstoffe für die Bewertung der Roggenqualität. Getreide, Mehl Brot 1966, 16, 21-26.

(23) Weipert, D. Processing performance of rye as compared to wheat. Cereal Foods World 1997, 42, 706-709.

(24) Dörfer, J. Rheologische Untersuchungen an Roggenmehlsuspensionen bei Applikation hemicellulytischer Enzyme. Getreide, Mehl Brot 1990, 44, 330-332.

(25) Gan, Y. T.; Mcleod, J. G.; Scoles, G. J.; Campbell, G. L. Genetic and environmental influence on the extract viscosity of winter rye. Plant Breed. Seed Sci. 1996, 40, 93-102. 
(26) Rattunde, H. F. W.; Geiger, H. H.; Weipert, D. Variation and Covariation of Milling-Quality and Baking-Quality Characteristics Among Winter Rye Single-Cross Hybrids. Plant Breed. 1994, 113, 287-293.

(27) Wilde, P.; Weipert, D. Sprouting resistance in rye as influenced by environment and cultivar. In Proceedings from the Eight International Symposium on Pre-harvest Sprouting in Cereals 1998; Weipert, D., Ed.; Association of Cereal Research, Federal Centre for Cereal, Potato and Lipid Research: Detmold, Germany, 1999.

(28) Hansen, H. B.; Andreasen, M. F.; Nielsen, M. M.; Larsen, L. M.; Knudsen, K. E. B.; Meyer, A. S.; Christensen, L. P.; Hansen, A. Changes in dietary fibre, phenolic acids and activity of endogenous enzymes during rye bread-making. Eur. Food Res. Technol. 2002, 214, 33-42.

(29) Andreasen, M. F.; Christensen, L. P.; Meyer, A. S.; Hansen, A. Content of phenolic acids and ferulic acid dehydrodimers in 17 rye (Secale cereale L.) varieties. J. Agric. Food Chem. 2000, 48, 2837-2842.

(30) Weipert, D. Roggen: Sorte und Umvelt-2. Teil: Qualitätsmerkmale und Verarbeitungswert. Getreide, Mehl Brot 1998, 52, 259-263.

(31) Sepstrup Per, personal communication.

(32) ICC. Standard Methods of the International Association for Cereal Chemistry (ICC); Verlag Moritz Schäfer: Detmold, Germany, 1998.

(33) Knudsen, K. E. B.; Åman P.; Eggum, B. O. Nutritive value of Danish-grown barley varieties. I. Carbohydrates and other major constituents. J. Cereal Sci. 1987, 6, 173-186.

(34) Arbeitsgemeinschaft Getreideforschung Standard-Metoden für Getreide, Mehl und Brot; Verlag Moritz Schäfer: Detmold, Germany, 1994.

(35) AACC. Approved Methods of the American Association of Cereal Chemists, 9th ed.; AACC: St. Paul, MN, 1995.

(36) Martens, M.; Næs, T. Multivariate Calibration; Wiley: New York, 1993.
(37) The Unscrambler. The Unscrambler-User's Manual; CAMO ASA: Oslo, Norway, 1998.

(38) Andreasen, M. F.; Christensen, L. P.; Meyer, A. S.; Hansen, A. Ferulic acid dehydrodimers in rye (Secale cereale L.). J. Cereal Sci. 2000, 31, 303-307.

(39) Chmielewski, F. M.; Kohn, W. Impact of weather on yield components of winter rye over 30 years. Agric. For. Meteorol. 2000, 102, 253-261.

(40) Meuser, F.; Suchow, P. Non-starch polysaccharides. In Chemistry and Physics of Baking; Blanshard, J. M. V., Frazier, P. J., Galliard, Eds.; The Royal Society of Chemistry: London, U.K., 1986.

(41) Weipert, D. Roggen: Sorte und Umvelt-1. Teil: Indirekte Qualitätsmerkmale. Getreide, Mehl Brot 1998, 52, 208-217.

(42) Bengtsson, S.; Andersson, R.; Westerlund, E.; Aman, P. Content, Structure and Viscosity of Soluble Arabinoxylans in Rye Grain from Several Countries. J. Sci. Food Agric. 1992, 58, 331-337.

(43) Vinkx, C. J. A.; Reynaert, H. R.; Grobet, P. J.; Delcour, J. A. Physicochemical and Functional-Properties of Rye Nonstarch Polysaccharide. 5. Variability in the Structure of Water-Soluble Arabinoxylans. Cereal Chem. 1993, 70, 311-317.

(44) Vinkx, C. J. A.; Stevens, I.; Gruppen, H.; Grobet, P. J.; Delcour, J. A. Physicochemical and Functional-Properties of Rye Nonstarch Polysaccharides. 6. Variability in the Structure of WaterUnextractable Arabinoxylans. Cereal Chem. 1995, 72, 411-418.

(45) Scoles, G. J.; Campbell, G. L.; Mcleod, J. G. Variability for grain extract viscosity in inbread lines and an F2 population of rye (Secale cereale L.). Can. J. Plant Sci. 1993, 73, 1-6.

Received for review October 21, 2003. Revised manuscript received January 26, 2004. Accepted January 28, 2004. This work is part of the Danish Cereal Network supported by the Ministry of Food, Agriculture and Fisheries.

JF0307191 